
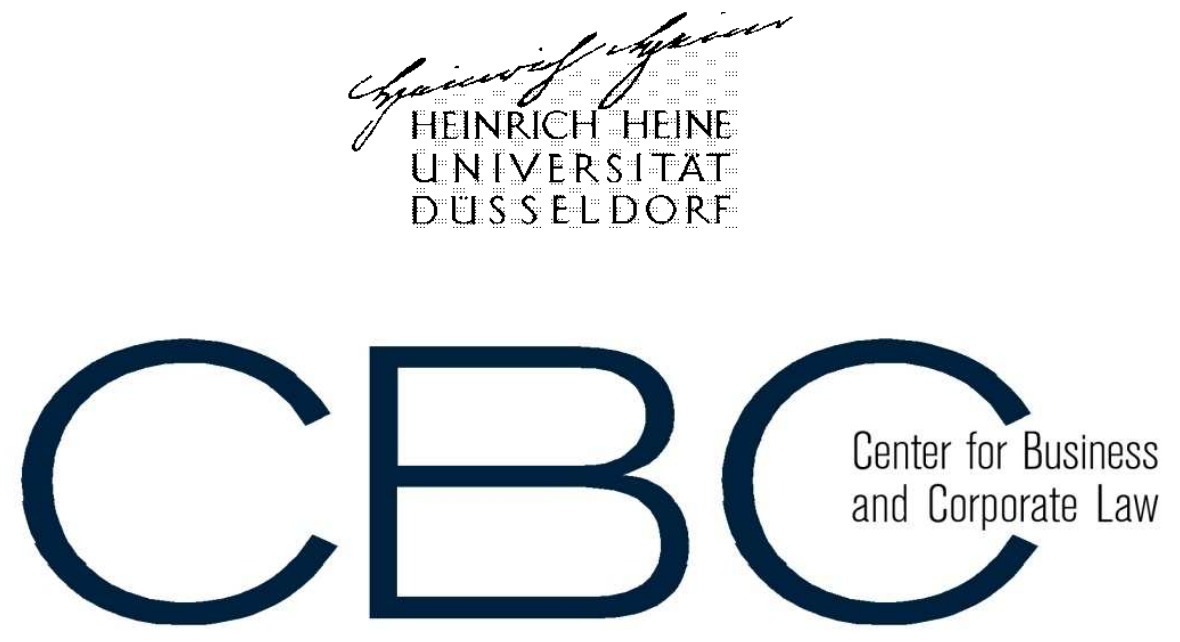

Heinrich-Heine-Universität Düsseldorf

- Juristische Fakultät -

Arbeitspapiere des Instituts für Unternehmensrecht (IUR)

Heinrich-Heine-University Duesseldorf / Germany

- Faculty of Law -

Center for Business and Corporate Law Research Paper Series (CBC-RPS)

http://iur.duslaw.eu/de

Autor / Author (E-Mail):

\section{E-Mail:}

Titel / Title:

CBC Nummer / Number:

SSRN Nummer / Number:

Schlagworte / Keywords:

JEL Classifications:
Dirk A. Zetzsche

zetzsche [at] uni-duesseldorf.de

Against Mandatory Disclosure of Economic-only Positions referenced to Shares of European Issuers -Twenty Arguments against the CESR Proposal

$0049(6 / 2010)$

http://ssrn.com/abstract $=1559787$

Transparency, Ownership Disclosure, Contracts for Differences, Total Return Equity Swaps, Mandatory Disclosure, Disclosure, Notification of Major Shareholdings, Hidden Ownership, Shareholder activism, Takeover, Market Efficiency, Restoring American Financial Stability Act of 2010, Gesetz zur Stärkung des Anlegerschutzes und Verbesserung der Funktionsfähigkeit des Kapitalmarkts, .

G10, G30, G34, G38, K20, K22 


\title{
Against Mandatory Disclosure of Economic-only Positions referenced to Shares of European Issuers - Twenty Arguments against the CESR Proposal ${ }^{1}$
}

\author{
Dr. Dirk Zetzsche, LL.M. (Toronto) \\ Heinrich Heine University, Dusseldorf
}

\begin{abstract}
Following recent developments in some European jurisdictions, the Committee on European Securities Regulators (CESR) proposed "to extend major shareholding notifications to instruments of similar economic effect to holding shares and entitlements to acquire shares" on 9 February 2010. This initiative pushes for mandatory Economic-only Disclosure of Major Shareholdings in Europe (EOD). By providing twenty arguments against the CESR proposal, this paper seeks to spur a lively discussion as to whether mandatory EOD is desirable. It puts forward that European institutions are well-advised to refrain from implementing the CESR proposal in its current form. If at all, implementing a reporting requirement to regulators (Economic-only Reporting, EOR) and limiting EOD to very large positions, serves social welfare better than EOD and avoids major differences between future European securities law and future U.S. securities regulation.
\end{abstract}

Keywords: Transparency, Ownership Disclosure, Contracts for Difference, Total Return Equity Swaps, Mandatory Disclosure, Disclosure, Notification of Major Shareholdings, Hidden Ownership, Shareholder activism, Takeover, CESR, Market Efficiency, Restoring American Financial Stability Act of 2010, Gesetz zur Stärkung des Anlegerschutzes und Verbesserung der Funktionsfähigkeit des Kapitalmarkts.

\footnotetext{
${ }^{1}$ Dr. iur. (Duesseldorf), LL.M. (Toronto), Assistant Professor, Faculty of Law, Heinrich Heine University Duesseldorf, Germany. I am indebted to Daniel Awrey, Brian Cheffins, Alexander Helgardt, Sebastiaan Hooghiemstra, Matteo Gargantini and K. Ulrich Schmolke for their criticism and encouragement. All errors and omissions remain my own responsibility..
} 
Table of Contents

\section{Inhalt}

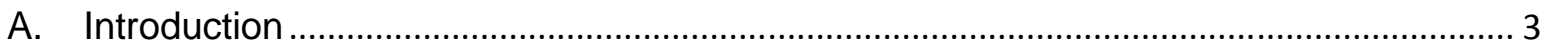

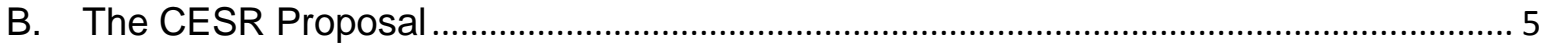

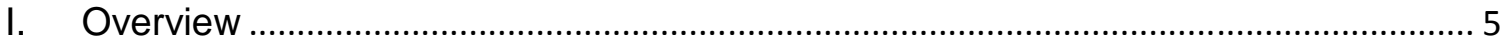

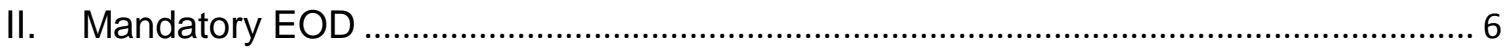

C. 20 Reasons against EOD as European Mandatory Law .............................................. 7

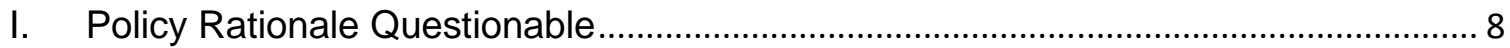

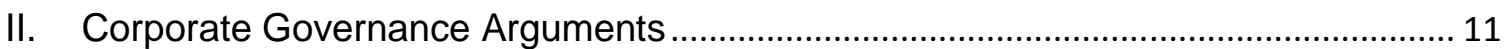

III. Market Efficiency Arguments ................................................................................ 13

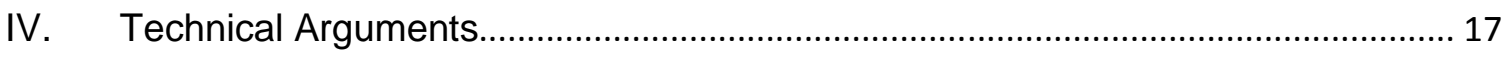

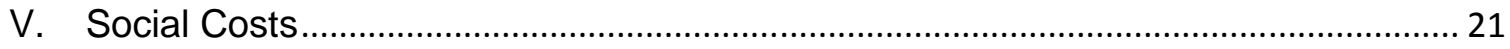

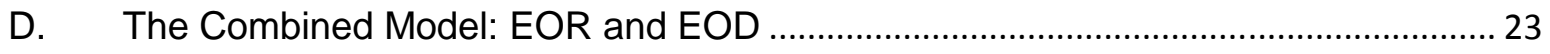

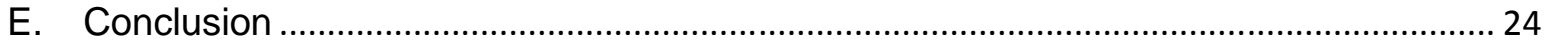

\section{A. Introduction}

Following the Swiss, ${ }^{2}$ British $^{3}$ and French ${ }^{4}$ rules on Economic-only Ownership Disclosure and similar Proposals in the Netherlands and Portugal, the Committee on European Securities

\footnotetext{
${ }^{2}$ Art. 20(2bis) of the Swiss law on Stock Exchanges and Securities Trading (BEHG) and Artt. 11, 13(1) of the Ordinance of the Swiss Banking Commission on Stock Exchanges and Securities Trading (BEHV-EBK); cf. C.H. Von der Crone, E. Bilek and M. Hirschle, 'Neuerungen im Offenlegungsrecht' (New Developments regarding Disclosure Rules), 80 Schweizerische Zeitschrift für Wirtschaftsrecht (SZW) (2008) pp. 1 and 4; U. Bertschinger, 'Finanzinstrumente in der Aktienrechtsrevision - Derivate, Securities Lending und Repurchase Agreements' (Financial Instruments and the Reform of Corporate Law - Derivatives, Securities Lendung and Repurchase Agreements), SZW 80 (2008) pp. 208 et seq.; P. Nobel, 'Neues Aktienrecht' (The New Corporate Law), 80 SZW (2008) pp. 175 and 188 et seq.

${ }^{3}$ No. 5.3, 5.7.1 and 5.8.2 (4) of the Disclosure Rules and Transparency Rules sourcebook (DTR) [part of the FSA Handbook]. Cf. Financial Services Agency, Disclosure and Transparency Rules (Disclosure of Contracts of Differences) Instrument 2009, prepared by Policy Statement PS 09/3 - Feedback on CP08/17 and final rules (March 2009); Disclosure of Contracts for Differences - Feedback and Policy Statement on CP07/20, CP08/17 (October 2008); Policy Update on Disclosure of Contracts for Difference (July 2008), and Disclosure of Contracts for Difference, Consultation Paper 07/20 (November 2007), all available at: http://www.fsa.gov.uk.

${ }^{4}$ Article L233-7 II (2) Code de Commerce as amended by Art. 2 (2) of Ordonnance $n^{\circ} 2009-105$ du 30 janvier 2009 relative aux rachats d'actions, aux déclarations de franchissement de seuils et aux déclarations d'intentions, entitles the AMF (l'Autorité des marchés financiers) to include financial instruments of similar economic effect to holding shares and entitlements to hold shares in the regulations requiring disclosure. These powers were
} 
Regulators (CESR) published its discussion paper "CESR proposal to extend major shareholding notifications to instruments of similar economic effect to holding shares and entitlements to acquire shares" (CESR/09-1215b) on 9 February 2010. Industry organizations in some European jurisdictions have been lobbying for the same policy goal; ${ }^{6}$ moreover, moreover, the German Ministry of Finance proposed to extend disclosure rules regarding cash-settled derivatives. ${ }^{7}$

This is not the place for oft-repeated arguments in favor of disclosure rules that include economic-only positions ${ }^{8}$ or to even summarize the extensive debate on disclosure of derivative positions. ${ }^{9}$ Instead, this paper summarizes 20 arguments - some of which have already been discussed in some EC Member States ${ }^{10}$ - about why disclosure of major economic-only positions (EOD), as proposed by CESR, is not desirable as part of mandatory European law. It states that, in light of the strong arguments against extensive disclosure rules, European institutions are well-advised to refrain from implementing the CESR

exercised by the Arrêté du 27 juillet 2009 portant homologation de modifications du règlement général de I'Autorité des marchés financiers (ECET0915539A, Journal officiel du 31 juillet 2009), amending the Règlement général de I'AMF - Livre II; see Article 223-11 (II) and 223-14 (III) (3) ("La déclaration précise en outre .. Les actions déjà émises sur lesquelles porte tout accord ou instrument financier, réglé exclusivement en espèces et ayant pour cette personne un effet économique similaire à la possession des dites actions.). The rules came into force 1 November 2009. Available at:

${ }^{5}$ Committee of European Securities Regulators (“CESR”), Consultation paper on proposed extension on major shareholding notifications to instruments of similar economic effect to holding shares and entitlements to acquire shares, CESR/09-1215b (9 February 2010), available at: < http://www.cesr-eu.org/popup2.php?id=6481>.

${ }^{6}$ For example, on 15 February 2010, the German industry organization BDI issued a Position Paper on Capital Market Transparency demanding, inter alia, mandatory EOD.

7 Cf. Bundesfinanziministerium [transl.: German Ministry of Finance], Diskussionsentwurf für ein Gesetz zur Stärkung des Anlegerschutzes und Verbesserung der Funktionsfähigkeit des Kapitalmarkts [Discussion draft bill on the Strengthening of Investor Protection and the Improvement of Capital Markets], 3 May 2010, available at: < http://www.bundesfinanzministerium.de>.

${ }^{8}$ Inter alia Henry T.C. Hu \& Bernard S. Black, "The New Vote Buying: Empty Voting and Hidden (Morphable) Ownership", Southern California Law Review 79, 811-908 and "Empty Voting and Hidden Ownership: Taxonomy, Implications and Reforms", Business Lawyer 61, 1011-1069 offer a disclosure reform proposal.

${ }^{9}$ See inter alia Reinier Kraakman, “Disclosure and Corporate Governance: An Overview Essay”, in: Ferrarini/Hopt/Winter/Wymeersch (eds.), Reforming Company and Takeover Law, p. 95 et seq. and Michael Schouten, The Case for Mandatory Ownership Disclosure (on SSRN) argues in favor of extending disclosure rules.

${ }^{10}$ See inter alia Holger Fleischer/Ulrich Schmolke, „Das Anschleichen an eine börsennotierte Aktiengesellschaft. Überlegungen zur Beteiligungstransparenz de lege lata und de lege ferenda“ (transl.: Sneaking up on quoted companies. Considerations on transparency of major shareholdings de lege lata and de lege ferenda), Neue Zeitschrift für Gesellschaftsrecht 2009, 401 and the citations in the following notes. 
proposal. Instead, this paper proposes a combination of reporting requirements to regulators (Economic-Only Reporting, EOR) and EOD.

It is structured as follows: part B summarizes the key features of the CESR proposal, part C provides a critical analysis of the CESR proposal, part D concludes.

\section{B. The CESR Proposal}

\section{Overview}

CESR states its objectives as follows (CESR/09-1215b, Para. 2 - 5):

"2. Instruments that create a similar economic effect to holding shares and entitlements to acquire shares effectively create a long economic exposure to the issuer. Currently these instruments are outside the legal scope of the Transparency Directive (TD). CESR intends to widen this scope to include all instruments referenced to shares that allow the holder to benefit from an upward movement of the price of these shares.

3. There is a range of instruments that can be used to create a similar economic effect, and a long economic exposure, to those financial instruments already captured under the TD without giving legal title to or the legal right to acquire the underlying shares, including certain options, equity swaps and Contracts for Difference (CfDs). Several member states have taken or are planning to take steps to broaden the scope of their national regime for the reporting of major holdings to include such instruments or to establish specific disclosure rules regarding them. The minimum harmonization required by the Transparency Directive allows for these national initiatives.

4. This consultation offers a high-level issues paper proposing to extend major holdings notifications to include all instruments that give a similar economic effect to holding shares and entitlements to acquire shares in the broadest sense. CESR considers that a broad definition balances the need for legal certainty with the potential for avoidance. The intention is to cover all instruments that can be used to create an economic long position.

5. While seeking to broaden the scope of the TDs major shareholding disclosure regime, CESR does not seek to change the general principles underlying the current regime. The scope of the broadened disclosure regime is to remain limited to 
instruments referenced to shares to which voting rights are attached, already issued, of an issuer whose shares are admitted to trading on a regulated market."

CESR goes on to summarize the scope of the Transparency Directive 2004/109, which currently regulates the minimum level of transparency rules relating to major shareholdings in Europe (sub II.), provides its view on issues deriving from instruments of similar effects to holding shares and entitlements to acquire shares (sub III.), and refers to five cases ${ }^{11}$ which it sees as evidence for the issues stemming from economic-only positions (sub IV.) as well as the national initiatives mentioned supra A. (sub V.). The remainder of the CESR proposal is a questionnaire dealing with the general desirability of reporting positions in instruments of similar effect to holding shares and entitlements to acquire shares, and making these requirements subject to the mandatory provisions of the Transparency Directive (sub VI.), the definition of instruments to be considered as those having a similar effect (sub VII.), the calculation of thresholds (sub VIII.) and the scope of disclosure of these instruments (IX.). CESR concludes with questions relating to costs and benefits of the proposed extension to disclosure rules (IX.).

\section{Mandatory EOD}

The CESR proposal extends to "instruments that create a similar economic effect to holding shares and entitlements to acquire shares". The term taken from the British CFD Rules ${ }^{12}$ is misleading. According to corporate law doctrine, shares grant cash flow and rights to participate in the control of the issuer. The former consist of the right to receive dividends and the residual claim in case of liquidation, while the latter include voting and information rights, as much as the right to sue management in certain situations. ${ }^{13}$ One would thus assume that CESR aims at reporting of positions that in addition to cash flow participation grant some indirect influence over control rights, i.e. disclosure of positions, which is commonly referred to as Hidden Ownership. ${ }^{14}$

\footnotetext{
${ }^{11}$ Continental/Schaeffler; Volkswagen/Porsche; FIAT; CSX/TCI; Implenia/Laxey Partners.

12 Supra n. 3.

${ }^{13}$ See on individual and collective interest suits Vermeulen, Erik P. M. and Zetzsche, Dirk A., The Use and Abuse of Investor Suits: An Inquiry into the Dark Side of Shareholder Activism (January 25, 2010). European Company and Financial Law Review, Vol. 7, No. 1; TILEC Discussion Paper No. 2010-001; CBC-RPS Paper No. 1/2010. Available at SSRN: http://ssrn.com/abstract=1428901.

${ }^{14}$ H.C. Hu and B.S. Black, 'Hedge Funds, Insiders, and the Decoupling of Economic and Voting Ownership: Empty Voting and Hidden (Morphable) Ownership', 13 J. Corp. Fin. (2007) p. 343; 'The New Vote Buying: Empty Voting and Hidden (Morphable) Ownership', 79 South. Cal. L. Rev. (2006) p. 811; 61 Bus. Lawy. (2006) p. 1011; 'Debt, Equity, and Hybrid Decoupling: Governance and Systemic Risk Implications', 14 Europ. Fin. Man. (2008) p.
} 
This is not the case. Para. 8 , sent. 1 and sent. 2 of the proposal reveals CESR's intentions:

"It should also be noted that instruments that create similar economic effect to holding shares and entitlements to acquire shares are generally entered into to give economic exposure without wishing to gain access to voting rights, and are an important source of liquidity to the market. CESR does not seek to discourage the use of such instruments, but only to make their resulting economic exposure transparent."

And in Para 48:

"A non-exhaustive list of instruments that are in scope may serve as guidance to the market. Such a list might include convertibles (bonds exchangeable for shares), writing of put options (European and American, in and out of the money), futures and forward contracts, Contracts for Difference (CfD), equity swaps, warrants, baskets and share indices "

In section IX. of the proposal, CESR discusses two alternatives: a disclosure requirement with broad scope and certain exemptions for market intermediaries and book keeping purposes, and a limited approach focusing on whether the holder has, in fact, access to voting rights or influence on the exercise of voting rights. CESR sees a number of concerns relating to enforcing a limited approach and proposes to implement a broad disclosure requirements with exemptions (Para 68, 74).

The CESR proposal extends to reporting any derivative position which is referenced to shares listed at regulated markets subject to certain exemptions. If the CESR proposal is implemented any economic position on shares will be subject to reporting requirements, regardless of whether there is any influence on the control rights stemming from the referenced shares. I refer to this reporting requirement as Economic-only Disclosure (hereafter EOD), in contrast to Voting Rights Disclosure (hereafter VRD), which has been implemented by regulators worldwide, and which is the dogmatic rationale behind the reporting requirements laid down in Articles 9 through 13 of the Transparency Directive 2004/109.

\section{20 Reasons against EOD as European Mandatory Law}

While the proposal is presented as a questionnaire, it is in fact a pre-arranged policy initiative by the collective securities regulators in Europe through the backdoor. ${ }^{15}$ As CESR does not

663; ‘Empty Voting and Hidden (Morphable) Ownership’, M\&A Lawyer (March 2007) at pp. 9-12; 'Debt and Hybrid Decoupling: An Overview', The M\&A Lawyer, Vol. 1 (April 2008) pp. 4-10.

${ }^{15}$ Cf. Para. 2 cited supra B. stating that "CESR intends to widen the scope" of the Transparency Directive. 
officially have rule-making power, the CESR move indicates that the powers which the Lisbon treaty grants to the European Commission and the European Parliament are de facto assumed by administrative branches. To the same extent that changes later on in the legislative process are less likely due to the determinative power of administrative "proposals", it is necessary to devote significant effort to the discussions which are initiated on the sub-levels of European administration.

By making twenty points arguing against the CESR proposal, this paper seeks to spur a lively discussion as to whether EOD is, in fact, desirable. The list of arguments is structured as follows. I question the policy rationale behind the CESR proposal (sub I.), before focusing on corporate governance (II.) and market efficiency (III.) concerns. I go on to present arguments relating to the substance, structure and reality of European securities law (IV.). I conclude with perspectives concerning whether the CESR proposal is appropriate for increasing welfare in the EU (V.).

\section{Policy Rationale Questionable}

CESR does not dwell on the rational for its EOD proposal. A second look reveals, however, that the rationale for EOD is far from obvious.

\section{1) The Transparency Directive's policy rationale does not support EOD.}

Under VRD rules, the disclosure of major shareholdings reveals a greater level of shareholder influence on management. This disclosure serves three purposes. First, the market can assume a greater level of shareholder monitoring of management which may turn into a lower level of management-related agency costs and thus a higher value creation of management. Secondly, the market may consider other consequences of a greater level of shareholder control, in particular a greater level of shareholder-related agency costs, or a pending change in control, respectively. Finally, society may consider the potential impact of a pending concentration of shareholdings on other stakeholders (employees, communities).

In contrast, EOD is a blurred signal that does not serve the same purposes. Neither does it signal a greater level of monitoring nor a pending change in control.

CESR states that "it does not seek to change the general principles underlying the current regime." The current regime (Transparency Directive) is based on VRD. Despite said intention, EOD is changing the general principles of the TP. It requires investors that engage in, let's say, purely value-oriented trades to disclose their trading activity. This is not related, to any extent, to influencing issuers by virtue of directly or indirectly exercising control rights.

2) The list of cases provided by CESR does not substitute a sound policy rationale. 
CESR lists five cases as evidence for the policy requirement. Examples offer no substitute for a clear statement regarding which conduct should be countered in detail. In order to counter the impression that CESR responds to pressure by certain interest groups (in particular, lobbyism by corporate management) rather than pursuing the benefit of society, in general, CESR is well advised to clarify which purpose in detail it seeks to achieve.

Two alternatives may have potentially provided the ground for the CESR proposal. First, EOD may be meant to support the TP Disclosure as an early warning system for pending takeovers (corporate governance perspective). If this is the case EOD throws out the baby with the bath water (infra C. II.). It is preferable to think about options to insulate Hidden Ownership from economic-only positions. ${ }^{16}$ Secondly, EOD may be justified by an expected rise in market efficiency. As pointed out infra (C.III.), this is not the case.

\section{3) The cases provided by CESR as examples for a policy requirement do not support the CESR's proposal.}

In all cases mentioned by CESR, the secret acquisition strategy backfired. In CSX/TSX ${ }^{17}$ and Implenia/Laxey Partners, the secret acquisition scheme was ruled to have been illegal. In the Fiat case, regulators have imposed sanctions; the case is still in court and the outcome is uncertain. $^{18}$ While BaFin could not find evidence for unlawful conduct in the Schaeffler/Continental case, the fact that the conduct was ruled to have been legal served rather than harmed Continental's dispersed shareholders, given the impact of the changing economic environment on Continental's share price. ${ }^{19}$ Finally, Porsche AG lost its independence due to the use of derivatives when taking over Volkswagen. It may be added that, in the Porsche case, the sudden creation of market upheaval was not due to the use of

\footnotetext{
${ }^{16}$ As an initial theoretical study, see Zetzsche, Challenging Wolf Packs: Thoughts on Efficient Enforcement of Shareholder Transparency Rules (2/2010), available on SSRN:

http://papers.ssrn.com/sol3/papers.cfm?abstract id=1428899.

${ }^{17}$ See U.S. District Court for the Southern District of New York, 11 June 2008, Case 1:08-cV-02764-LAK - CSX v. The Children's Investment Fund (TCI) -, confirmed by summary order No. 08-2899-cv (2nd Cir. Sept. 15, 2008). See also J. Coffee, 'Regulators Need to Shine a Light on Derivatives', Financial Times (30 June 2008) p. 13. The question of civil damages for "short-swing" profits under s. 16(b) of the SEA was settled for \$11 m, while CSX identified potential recoverable damages of approx. \$138 m, see Theodore Mirvis, Hedge Funds Settle "Short Swing" Profits Litigation, Harvard Law School Corporate Governance Blog, 28 December 2008.

${ }^{18}$ Statement is subject to review by author.

${ }^{19}$ In light of tumbling stock prices under the influence of the financial crisis, a tender offer made at an offer price that was calculated prior to Lehmann Brothers' insolvency and thus assumed better economic conditions than were justified in light of the dawning depression was preferable to having no tender offer at all. See Zetzsche, (2009) 10:1 EBOR 115, as working paper online: http://papers.ssrn.com/sol3/papers.cfm?abstract id=1170987 .
} 
derivatives, per se, but due to prior statements from Porsche that it would not raise its positions over the level it had previously claimed.

\section{4) Secret acquisition schemes depend on leverage. Banks do not provide acquirers with credit to the same extent as they did prior to the financial crisis.}

As can be concluded from the discussion surrounding the scope of potential disclosure requirements (Para. 61 et sequi) it is CESR's rationale to counter hidden ownership schemes that facilitate takeover attempts by acquiring a certain level of shares prior to disclosing one's shareholdings and intentions. In fact, we have seen a number of these schemes working in Europe (and beyond) in the past. However, the economic environment for secret acquisition schemes has changed. Banks have become subject to more stringent rules on lending, and the securitization market which was the backbone of leveraged buy outs (LBO) has ceased to exist. As derivative-based secret acquisitions rely on a form of credit, the likelihood of secret acquisitions taking place is diminished to the same extent as less credit is available.

\section{5) Acquirers learned the hard way: debt is discipline. In the future, only companies that deserve to be the subject of takeovers are likely to become targets.}

Market participants have learned that derivatives are neither an inexpensive nor a risk free way to take over companies. In contrast to fixed debt, the burden of derivative-based debt cannot be measured ex ante with certainty, as its size fluctuates in correlation with the referenced share. The experience with highly leveraged secret acquisitions schemes such as Volkswagen/Porsche and Continental/Schaeffle ${ }^{20}$ renders secret acquisitions less likely than prior to the crisis.

Given the expenses and economic and regulatory risks associated with derivative-based acquisitions - rational actors consider risks when deciding upon secret acquisition strategies secret acquisitions are used merely if the target deserves to be taken over. Secret acquisitions are only worth the effort if the target's share price is depressed, or if a merger is likely to exhibit significant economies of scale and scope, and only if the industrial logic overwhelmingly supports the takeover.

In the former case, secret acquisition strategies are not the reason for the share price being depressed (in fact, they support the share price, as hedging activity by the intermediaries involved creates demand for the referenced shares, infra B. II.). In the latter case, from an economic point of view, these takeovers are beneficial. Regulators must support rather than prevent these takeovers taking place.

\footnotetext{
${ }^{20}$ Schaeffler went almost bankrupt due to the burden caused by its shareholder bid and its derivative contracts. To this day, Schaeffler's conduct is strongly influenced by the banks who financed the Continental takeover.
} 


\section{6) Courts and regulators may counter obvious and blatant cases on the grounds of the existing European law.}

CESR acknowledges that certain instruments that do not give direct access to voting rights indirectly fall within the scope of Article $10 \mathrm{~g}$ ) of the Transparency Directive. The referenced shares are held 'on behalf' of the writer of the respective derivative if the writer bears the economic risk, and if they are able to exercise influence via the shares. ${ }^{21}$ Any Hidden Ownership requires by definition influence on voting rights in addition to economic exposure. On the basis of CESR's interpretation - which I share -, any undisclosed Hidden Ownership position that crosses the set thresholds is a violation of disclosure rules. Courts and regulators have also learned about the economics of derivative-based secret acquisition schemes. CSX/TSX and Implenia/Laxey Partners provide good evidence to this fact. The courts and regulators developed methods to deal with blatant cases of circumventing VRD. There may be counter examples. However, the more regulatory expertise assembled the less likely is it that speculative - and spectacular ! - takeovers succeed by virtue of a hidden acquisition strategy. ${ }^{22}$

\section{Corporate Governance Arguments}

\section{7) Mandatory EOD shields management from takeovers and curbs takeover activity in}

\section{Europe.}

Any strengthening of shareholder disclosure rules is likely to reduce investment in information about the true value of an issuer. ${ }^{23}$ Disclosure of a major shareholding signals under-pricing of the said shares on the stock markets (at least at the time of the purchase). Shareholders that do not invest in information may freeride on the signal provided by said disclosure and accumulate stocks of the respective issuer. In turn, the stock price increases which renders the takeover more costly. In addition, management may launch defensive measures early on, or even prior to the takeover bid, which render the takeover post disclosure even more expensive than the defensive measures launched after the acquisition of a significant or even a controlling stake in the firm. Consequently, if disclosure rules are too stringent, fewer buying opportunities are identified and fewer takeover offers are

\footnotetext{
${ }^{21}$ CESR/09-1215b), Para 16. For details see the author's argument supra n. 19.

${ }^{22}$ Again, additional considerations are likely to have influenced BaFin's decision of declaring Schaeffler's conduct to be legal, see supra n. 19. However, BaFin's decision did not bind any of the parties involved. The issuer, and / or Continental's shareholders, could have sued Schaeffler for breach of VRD rules. None did.

${ }^{23}$ S. Grossman \& J. Stiglitz, On the Impossibility of Informationally Efficient Markets, 70 Amer. Econ. Rev. 393, 405 (1980).
} 
launched. Mitigating takeover activity, in turn, reduces the disciplining effect of takeovers on management. As life gets easier for management, agency costs are likely to increase ${ }^{24}$ which is detrimental to (at least) the interests of dispersed stockholders.

The mitigating effect on takeovers is most extreme if EOD Rules are teamed up with low threshold requirements (as is the case in the UK).

\section{8) From a corporate entities perspective, mandatory EOD is neutral. EOD merely serves management's interests.}

Corporate entities may become subject to a bid to the same extent as the entity issues a bid for shares of some other corporate entity. The (perceived) advantage in the case of defending against a takeover bid turns into a disadvantage in the case of issuing a hostile bid. From the perspective of a corporate entity, EOD is neutral. However, from the perspective of management, keeping one's position is bound to a safer and thus higher expected return than a situation in which management is asked to look for a new job due to a takeover.

9) Mandatory EOD increases the discount on European shares, which, in turn, increases the likelihood of takeovers of European firms by non-European investors in certain jurisdictions.

As a response to EOD, global investors assume lesser takeover activity and thus higher agency costs. Moreover, legal uncertainty and unclear enforcement strategies may further curb the willingness to invest in one's shares. In turn, they will increase the discount required for purchasing certain European stocks. ${ }^{25}$ As a consequence, global investors will assign lesser value to shares of European issuers than shares of comparable firms from other jurisdictions (in particular, the U.S. where no disclosure of economic-only positions is

\footnotetext{
${ }^{24}$ Other arguments against broad-phrased disclosure rules include potential law suits and discouragement of overall monitoring: European Commission Report on More Stringent National Measures Concerning Directive 2004/109/EC, on the Harmonisation of Transparency Requirements in Relation to Information About Issuers whose Securities are Admitted to Trading on a Regulated Market, SEC (2008) 3033 final (2008), at 10; H. Fleischer and K. Schmolke, 'Kapitalmarktrechtliche Beteiligungstransparenz nach $21 \mathrm{ff}$. WpHG und "Hidden Ownership"' (Securities law-based Transparency of Shareholdings under ss. 21 et seq. WpHG and Hidden Ownership) 29 (33) Zeitschrift für Wirtschaftsrecht (ZIP) (2008) p. 1501 et seq.; Jonathan R. Macey \& Jeffrey M. Netter, Regulation 13D and the Regulatory Process, 65 Wash. U.L.Q. 131, 144 (1987); Bernhard Black, Next Steps in Corporate Governance Reform: 13D Reuls and Control Person Liability, in: K. Lehn \& R. Kamphuis eds., MODERNIZING US SECURITIES REGULATION: ECONOMIC AND LEGAL PERSPECTIVES (1992), at 201 (raising concerns that institutional investors may be discouraged from monitoring).

${ }^{25}$ See, for instance, on the "Dutch Discount" McCahery/Vermeulen, Conflict Resolution and the Role of Corporate Law Courts: An Empirical Study, available at: http://ssrn.com/abstract=1448192., at p. 19 et seq.
} 
required). The lower valuation will attract acquirers from outside of Europe to take advantage of the lower evaluation.

The discount is likely to be the greater the smaller the jurisdiction is, as information costs relating to the law and enforcement of said jurisdictions earn the lowest returns, in relative terms, due to the limited number of issuers that are subject to these rules. Each jurisdiction is well-advised to calculate the expected upside (whatever this is) with the potential downside of a greater national penalty for the issuers under its surveillance.

While this argument counters a uniform European solution, it seems to weaken argument 7. However, both aspects - those presented in argument 7 and those presented in argument 9 - distort the pricing functions of capital markets. Rather than hoping for a balance of several distortive factors it is desirable to let securities markets price securities with as little legal interference as possible. VRD is much closer to that ideal than EOD in addition to VRD.

\section{Market Efficiency Arguments}

\section{0) If trading patterns from EOD are the same as those observed in a world of VRD, EOD is harmful to the pricing function of capital markets.}

EOD creates the risk of additional noise trading, i.e. transactions prompted by uninformed investors. ${ }^{26}$ While noise trading is likely to materialize in a world of VRD as well, ${ }^{27}$ VRD

\footnotetext{
${ }^{26}$ Rational, informed investors are the paradigm of investors whose activity renders market prices as a serious reflection of corporate value. These investors are able to detect the cases in which there is either significant under-evaluation or synergies - these are the cases in which the existing legal and economic environment are likely to be given (see argument 5).

In case of under-evaluation, rational informed investors will seek to trade on their information and push the market prices towards the correct price. In case of synergies, these investors are also likely to consider a potential takeover in their arrangements.

${ }^{27}$ Previous research has shown significant abnormal (short-term) returns upon first-time disclosure of major shareholdings. Although the premium for potentially passive investors is smaller, this is true for all types of investors that disclose major shareholdings. For potential industrial buyers: WH Mikkelson \& RS Ruback, An Empirical Analysis of the Interfirm Equity Investment Process, (1985) J. Finan. Econ. 14, 523 (1985); Clifford G. Holderness \& Dennis P. Sheehan, Raiders or Saviors? The Evidence on Six Controversial Investors, (1985) 14 J. Fin. Econ. 555 (1985); Steven R. Bishop, Pre-Bid Acquisitions and Substantial Shareholder Notices, (1991) 16 Australian J. Manage 1 (1991); for activist investors / hedge funds: Along Brav, Wei Jiang, Frank Partnoy, Randall Thomas, Hedge Fund Activism, Corporate Governance, and Firm Performance, (2008) Journal of Finance 63:4, 1729-75; abnormal returns of 5\% - 7\% within 20 days; April Klein, Emanuel Zur, Hedge Fund Activism, London 2007: abnormal returns of 10\% within 30 days; Mark Mietzner, Denis Schweizer, Hedge funds and Private Equity: Differences in Value Creation, Oestrich-Winkel (EBS), 2008: abnormal returns with 2 times 20 days; Robin M. Greenwood \& Michael Schor, Investor Activism and Takeovers (2008), at 29, available at SSRN:
} 
provides a clear signal and thus reasons for abnormal returns (better monitoring, increase in demand due to a pending takeover). This is not the case in a world of EOD. As EOD does not differentiate between control put to use and purely economic participation, EOD sends a noisy signal to the market. Noise trading impacts on the pricing function of capital markets (with its related corporate governance signals and inherent regulation of capital flows etc.). ${ }^{28}$ Other shareholders buy and sell the shares at the wrong price. In turn, the stock price sends a less reliable signal for expected future cash flows and serves a less reliable purpose in guiding flows of capital to their most productive uses. The likelihood of asset bubbles (with an ensuing crisis) increases.

One could argue in favor of CESR by stating that EOD is better than no information. Such a statement is not necessarily true. The marginal benefits of disclosure may well be negative, and this is likely the case in a world of EOD.

While this is not CESR'S proposal, one could consider mandating separate disclosure for VRD and EOD. Keep in mind that, if there is influence, the hidden ownership definition applies and disclosure is required under Art. 10g) of the Transparency Directive. If VRD requirements can be identified as such and hence enforced - why do we need EOD, in addition to VRD?

\section{1) EOD is harmful to the liquidity of capital markets.}

Assuming that EOD prompts the same trading patterns as VRD, when purchasing shares upon disclosure, uninformed traders freeride on the informed trader's investment. EOD then assigns some of the profits that belong to the informed trader who has invested in the respective information to the noise trader. As informed traders cannot fully capitalize on their investment, informed trading is discouraged, in general. This is particularly true since investors are not tied to the public stock markets. As a response to EOD, potential acquirers

http://ssrn.com/abstract=1003792. For passive investors: Christopher Clifford, Value Creation or Destruction?

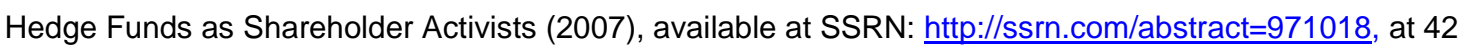
(comparing s. 13D and $13 \mathrm{G}$ filings, showing a premium of $1.74 \%$ for passive and $3.44 \%$ for active investors). These studies are confirmed by announcements in 2006 surveyed by the Financial Services Agency, Disclosure of Contracts for Differences, Consultation and Draft Handbook Text (CP 07/20) (2007), annex 3, p. 14. For informed traders who are unlikely to pursue activist strategies (such as mutual funds), see Aslihan Bozcuk \& M. Ameziane Lasfer, The Information Content of Institutional Trades on the London Stock Exchange, 40 J. Finan. Quant. Anal. 621, 631 (2005); Bishop, ibid, at 19.

\footnotetext{
${ }^{28}$ There are two alternatives: First, let's assume that the share price has not yet reached the limit price, i.e. the maximum value which the rational investor assigns to the shares (LP). By purchasing shares, they press the share price towards LP. Secondly, let's assume that the share price has reached LP by the time of disclosure. By purchasing shares, uninformed traders press the share price over LP. Neither of the consequences are desirable.
} 
may make profitable acquisitions in the private equity or commodity domain. The departure of these investors reduces the liquidity of the stock markets, in general. ${ }^{29}$ Reduced liquidity is likely to have a negative impact on both the price discovery function and price sensitivity of the stock markets.

Moreover, EOD prompts additional costs to market participants (infra C.V.). These costs are either direct reporting and related costs or indirect costs, stemming from an increase, or a smaller decrease in trading fees respectively. ${ }^{30}$ Any additional cost on trading can be seen as a tax. From an overall perspective, EOD can be understood as a tax put on all market participants using derivatives. It is generally accepted that markets work best (in terms of price discovery and sensibility) in a state where transaction costs are low. To the extent that EOD increases transaction costs, it reduces the efficiency of derivatives markets, and thus an important feature of securities markets, in general.

As previously mentioned, CESR has not clarified which policy goal in detail it seeks to achieve with EOD. If CESR seeks to lessen the overall volume of derivative transactions, a direct tax on derivative transactions is, from the tax payer's perspective, both more advantageous and transparent.

\section{2) Hedges lift stock prices to an acceptable level (albeit not the highest competitive level possible)}

The secret acquisition strategies which CESR seeks to counter rely on the use of derivatives. The intermediaries involved in these schemes tend to hedge their risks by purchasing stock over the stock markets. ${ }^{31}$ In turn, if an acquirer increases its derivative position, the stock price of the referenced share on public stock markets is also raised. ${ }^{32}$ Thus, even before the acquirer discloses its stake, the stock price is influenced by the additional demand created by hedges assembled by the intermediaries involved. While this is not the highest level possible under circumstances of competing bids issued in a state of perfect competition, the stock price is likely to be higher than for a state where there is no derivative-based demand due to the secret acquisition strategy.

\footnotetext{
${ }^{29}$ This happens for two reasons. first, investors whose hedging activity is restricted due to higher costs and/or disclosure trade less in both derivatives and stocks. Secondly, investors trust the pricing function of capital markets to a lesser extent which implies a higher level of information costs for any individual transaction. Higher information costs in turn prompt less profitable trading, in general.

${ }^{30}$ Compliance costs are part of the cost base from which trading fees are calculated.

${ }^{31}$ See Zetzsche, supra n. 16 and infra n. 19.

${ }^{32}$ The Continental/Schaeffler case provided evidence to this statement, see Zetzsche, supra n. 16 and infra n. 19.
} 
Admittedly, in light of the semi-strong form of market efficiency with which temporary capital markets are associated, it is not easy to explain why the additional demand should create higher securities prices. Theoretically, arbitrage should drive the security prices back to their original level, i.e. the level without the additional demand. However, in reality this looks different. Besides limits on market efficiency and / or arbitrage (such as limited credit, etc.) one possible explanation is that the additional turnover created by the additional demand is the information itself which securities markets read as a signal for some type of insider information. The other explanation is that the acquirer cannot effectively control inside information, i.e. that markets respond to rumors.

\section{3) CESR's approach is not consistent with its short selling regime.}

In order to avoid a regulatory incentive for trading either long or short positions, regulators are well-advised to harmonize costs for long and short positions. CESR generally acknowledges the need for harmonizing long and short trading requirements. Para. 7 states:

"Where appropriate, this consultation proposes an approach that is consistent with the pan European short selling regime proposed by CESR's Task Force on Short Selling. It should be noted, however, that CESR considers these are two separate regimes that serve different purposes."

The extent to which the CESR EOD proposal is consistent with the short-selling regulation is neither clarified by CESR, nor is it obvious by itself. While regulating short-selling is equally subject to concerns, regulators justify the recent wave of short-selling regulation with market efficiency concerns. In Para. 44 CESR states:

"[A pan-European short selling disclosure regime] seeks to address issues of market abuse and disorderly markets. The scope of the short selling disclosure regime includes all holders of net short positions, and is not limited to shareholders who hold a gross long position.

In contrast, the CESR EOD proposal is justified with unclear policy concerns and limited to shareholders who hold large long positions.

On a different note (unrelated to the CESR proposal), Empty Voting is a type of behavior associated, inter alia, with short selling. However, it is unconnected with this issue as we are dealing with short rather than long positions. Corporate law in most European jurisdictions 
provide for efficient ways of dealing with the corporate governance impact of short selling. ${ }^{33}$ This perspective does not warrant additional regulation.

\section{IV.Technical Arguments}

\section{4) EOD contradicts other EC initiatives that seek to further shareholders' rights and a level playing field for takeovers in cross-border Europe.}

The Shareholders' Rights Directive ${ }^{34}$ is designed to strengthen shareholder influence vis-àvis management. The Takeover Directive seeks to achieve a level playing field and reduce restrictions for takeovers in Europe.

The effectiveness of both measures is in doubt if EOD becomes mandatory: only shareholders, whose overall economic stake reaches a certain threshold, have adequate incentives to monitor management. If the same type of sanctions applies to shareholdings and derivative positions, investors become subject to forfeiture of rights as a penalty for violating EOD rules, even in the absence of any intention to issue a takeover bid or to influence the issuer. ${ }^{35}$ Moreover, under EOD Rules takeovers are likely to become more expensive and thus less likely in general (supra B.II.). Both consequences contradict the objectives of the respective directives.

15) EOD seeks to curb Hidden Ownership. Hidden Ownership is a corporate governance issue. Corporate law may provide other, less costly solutions. CESR does not have expertise and jurisdiction to deal with corporate governance.

CESR is a committee of European securities regulators. While formally dealing with disclosure requirements, it is de facto regulating, and impacting on corporate governance rather than market efficiency. Some of the European financial market authorities being members of CESR have neither expertise nor jurisdiction of dealing with corporate governance. ${ }^{36}$ Since each institution has a tendency to emphasize its own importance, it is

\footnotetext{
${ }^{33}$ See, for example, Gregor Bachmann, Rechtsfragen der Wertpapierleihe (transl. Legal Questions Relating to Securities Lending), Zeitschrift für das gesamte Handels- und Wirtschaftsrecht 173 (2009), Vol. 5; Ulrich Noack and Dirk Zetzsche, in: Ulrich Noack / Wolfgang Zöllner (eds.), Kölner Kommentar zum Aktiengesetz (transl. Cologne Commentary to the Stock Corporation Act), 3rd. Ed., Cologone 2010, re s. 123 AktG ๆ 86*.

${ }^{34}$ Directive 2007/36/EC of the European Parliament and of the Council of 11 July 2007 on the exercise of certain rights of shareholders in listed companies (14 July 2007).

${ }^{35}$ See forfeiture of rights as penalty for violation of disclosure rules Zetzsche, supra n. 19. Under the current German law, forfeiture of rights does not extend to call options, see s. 28 WpHG (Securities Trading Law).

${ }^{36}$ In particular, the German Bundesanstalt für Finanzdienstleistungsaufsicht.
} 
likely that - regardless of the quality of alternative policy approaches and societal benefits approaches based on securities law are over- and corporate law-based approaches underemphasized when considering the use of derivatives. Excluding corporate law is not desirable as it furthers imperfect, rather than the best solutions from being implemented.

As an alternative to EOD, corporate statutes - following a shareholders' resolution to that extent - could require the registration of shareholders in a share register, or a bank certificate certifying a share holding to that extent for a certain time ${ }^{37}$ prior to issuing a takeover bid (or a shareholders' meeting where shareholders elect directors, respectively), as a precondition for issuing a takeover bid (or exercising voting rights, respectively), if the overall holding exceeds certain thresholds (for example: $10 \%$ or $15 \%$ ).

While such a corporate law-based solution, based on the registration of shares, is not necessarily takeover friendly, in contrast to EOD, it focuses on secret acquisitions designed to control the company, while it does not impact on market efficiency. Moreover, such a solution is in the same spirit as Articles 11 and 12 of the Takeover Directive 2004/25. These provisions lay the decision as to whether a company wants to be open to takeover in the hands of shareholders, rather than management, as EOD Rules effectively do.

\section{6) Better and more efficient enforcement of existing rules is preferable to drafting new, equally imperfect rules.}

The effectiveness of EOD, as with all disclosure rules, depends on enforcement. EOD Rules counter the derivative-based (Service) strategies for secret acquisitions ${ }^{38}$ effectively only to the extent that financial intermediaries (investment banks, trustees, etc.) are subject to European financial supervision. This may not be the case if shell companies are involved that reside beyond European borders. World-wide enforcement of European securities laws is still a vision rather than a reality. In addition, EOD does not counter the Equity Strategy which is based upon acting in concert and other methods relying on gentlemen's agreements (wolf packs). ${ }^{39}$ If EOD Rules are implemented, the Equity Strategy is likely to flourish.

Instead of drafting new rules that do not cover all potential strategies of circumventing VRD, regulators are well advised to think about how existing VRD rules can be enforced more stringently. ${ }^{40}$

\footnotetext{
${ }^{37}$ For example, the period of time which is relevant for setting the adequate compensation in a takeover bid.

${ }^{38}$ For a description and analysis of secret acquisition schemes see Zetzsche, supra note 16.

${ }^{39}$ Supra n. 16.

${ }^{40}$ For a proposal, see Zetzsche, supra n. 16.
} 


\section{7) The FSA CFD Rules do not provide a good role model for Europe.}

The FSA was the first financial market authority to discuss and adopt EOD within the European Union. It is likely that France as well as CESR borrowed from the English CFD Rules when initiating EOD. The best (?) solution for the English securities markets is not necessarily the best solution for Europe. In fact, the British capital markets provide an inadequate role model for Europe. Stamp tax has reduced the meaning of the English (direct) stock markets. The $0.5 \%$ rate of British Stamp Duty Reserve $\operatorname{Tax}^{41}$ is far higher than in other European jurisdictions; in most jurisdictions no stamp tax is collected at all on stock trades. British investors are increasingly shunning traditional share purchases in favor of derivatives such as CFDs, to which the stamp tax does not apply. In addition, the settlement costs are high, in relative terms: a lesser flow of equity trading induces less investment in the efficiency of trading and settlement infrastructure of stock exchanges (while spurring the efficiency of derivative trading platforms).

In such an environment, requiring EOD is subject to different considerations than in an environment where most trade in stocks are directly traded and settled over stock exchanges. A broad, all-inclusive EOD Rule is not the best rule for European jurisdictions that refrain from demanding stamp tax, and, in the past, have invested in efficient trading and settlement infrastructure of their equity markets (in contrast to, or alongside with, derivative markets). One size does not fit all.

\section{8) Disclosure of economic-only positions is not necessary for achieving the purpose} CESR seems to be pursuing.

CESR apparently seeks to implement EOD as an enforcement measure against secret acquisition schemes. Disclosure of economic-only positions (which reduces market efficiency and impacts on corporate governance to the extent that it renders takeovers less likely, supra under 3.2. and 3.3, is not necessary for better enforcement. Under the U.S. Treasury's proposed comprehensive regulatory framework ${ }^{42}$ that is likely to be adopted as

\footnotetext{
${ }^{41}$ Stamp Duty Reserve Tax (SDRT) applies only to transfers of stock and marketable securities, and to certain transfers of interest in partnerships. Moreover, investors purchasing units from a fund manager are not charged SDRT. But when units are surrendered the fund manager is charged SDRT.
}

See http://www.hmrc.gov.uk/sdrt/intro/basics.htm .

42 The U.S. Treasury's 'proposed framework' was outlined in a letter dated 13 May 2009 from United States Secretary of the Treasury Timothy F. Geithner to a number of Congressional leaders (<http://www.financialstability.gov/docs/OTCletter.pdf>). See also Mr Geithner's written Testimony before the House Financial Services and Agriculture Committees on 10 July 2009 (<http://www.house.gov/apps/list/hearing/financialsvcs_dem/otc_derivatives_07-09-09_final.pdf>). 
part of the pending U.S. Restoring American Financial Stability Act of $2010^{43}$ and that would cover all derivatives including those traded over-the-counter, disclosure of security-based swap transaction and pricing data focuses on the enhancement of price discovery ${ }^{44}$ rather than corporate governance. Trading parties must either clear swap transactions over registered clearing agencies, or report the data of each transaction to security-based swap repositories or the SEC. ${ }^{45}$

However, only a small amount of data must be made available to the public. Generally speaking, on standard transactions the new rules would require "timely information on price, trading volume, and other trading data on security-based swaps to the extent prescribed by the" SEC. ${ }^{46}$ It follows from the disclosure requirement for non-standard swaps $^{47}$ that disclosure extends to aggregate data on security-based trading volumes and positions, but must not reveal any person's business transactions and market positions. Despite some spectacular derivative-based takeovers in the U.S., the pending U.S. legislation refrains from disclosure of any large security-based derivative position. S. 13(d) (1) of the SEA 1934 would grant rulemaking power to the SEC for derivate positions that result in beneficial ownership. ${ }^{48}$ Under the current U.S. securities regulation, in addition to

\footnotetext{
${ }^{43}$ On 11 December 2009, the U.S. House of Representatives passed the "Wall Street Reform and Consumer Protection Act of 2009" (H.R. 4173, the "House bill"). On 20 May 2010, the U.S. Senate passed the Restoring American Financial Stability Act of 2010 (Senate Bill 3217, the "Senate bill"). The framework is part of, cf. the House bill H.R. $4173 \S \S 3103,3104$ and 3203 and the Senate Bill $\S 763$ and 766 (version as of 29 April 2010 , available at http://www.govtrack.us/congress/billtext.xpd?bill=s111-3217). The following paragraph focuses on security-based swaps. Regarding other than security-based swaps, the Senate Bill would impose a similar requirement by amending the Commodity Exchange Act (7 U.S. Code 1, et seq.).

${ }^{44}$ Cf. new ss. $3 C(c)(B)$ and $10 \mathrm{~m}(1)(B)$ of the Securities Exchange Act of 1934 (15 U.S. Code § 78a, et seq., "SEA $1934 ")$.

${ }^{45}$ Cf. new ss. 3C(c) and 13A(a) SEA 1934.

${ }^{46}$ Cf. new s. 3D (d)(9)(A) SEA 1934.

${ }^{47}$ Under new ss. 3C(c)(C)(iii) and 10m(1)(C)(iii) SEA 1934, the U.S. Securities and Exchange Commission ("SEC") would "make available to the public, in a manner that does not disclose the business transactions and market positions of any person, aggregate data on" security-based trading volumes and positions.

${ }^{48}$ In addition to existing rules, new s. 13(d)(1) SEA 1934 would require disclosure by any person who "otherwise becomes or is deemed to become a beneficial owner of any of the foregoing [securities] upon the purchase or sale of a security-based swap or other derivative instrument that the Commission may define by rule" and that holds a position of $5 \%$ or more of the referenced shares. The same requirement is added to the disclosure of institutional investment managers under new s. 13(f)(1) SEA 1934.
} 
investment power, voting power is a precondition for beneficial ownership. ${ }^{49}$ VRD is likely to remain the U.S. standard.

The separation between reporting to regulators and disclosure to the public is due to the intellectual property which these trade details include. Along these lines, CESR could opt for a requirement to report to regulators, instead of for a requirement to notify the issuer. This idea will be extended below in section 4 .

\section{Social Costs}

\section{9) EOD is costly.}

EOD creates direct and indirect costs. Direct costs consist of both implementing and execution costs. EOD Rules must be drafted at a European level, implemented by the EC Member States and put into daily practice by investors, investment banks, and other market participants. The implementation costs amount to thousands of work hours charged to, or borne by, regulators, settlement institutions, investment banks, and issuers. In addition, while the new rules may only apply to a few shareholders, all shareholders become subject to compliance rules. In corporate reality, burdensome compliance is already more stringent, even for firms whose use of derivatives is not intended to result in a secret acquisition scheme.

Not only market entities with a (perceived) negative impact on issuers, and/or society, (such as 'hedge funds', 'private equity', 'foreign' investors, etc.) are subject to these costs, but also financial intermediaries that are involved in pension schemes, such as pensions funds, mutual funds, insurances, etc. Even if the marginal costs for the individual transaction is low, the overall costs for those who depend on the intermediary chain - the pensioners -, is likely to be significant. For a traditional pension scheme, these costs will be incurred on several layers, as all entities that serve pensioners use derivatives in many transactions (as the investment period for pension schemes is very long).

Equally harmful are the indirect costs associated with disclosure of derivative positions, as self-created private and possibly delicate information is disclosed to the market. This may de

\footnotetext{
${ }^{49}$ Cf. Rule $13 d-3$ (a) of the General rules and regulations promulgated under the Securities Exchange Act of 1934 (17 CFR Part 240).
} 
facto foreclose certain hedging strategies ${ }^{50}$ and force business parties and investors to bear a greater level of risk than is possible without EOD.

\section{0) If EOD is truly beneficial, there is no need for mandatory regulation at an EU level.}

Legislators opt for rules that are beneficial for their domain. If implementing EOD creates benefits to the respective jurisdiction, it will be implemented even in the absence of mandatory EU legislation.

Indeed, harmonizing disclosure rules completely across all European states may reduce rather than increase transaction costs of institutional investors that trade in all European states. ${ }^{51}$ However, if complete harmonization is intended, CESR suggests the wrong technical method. Amending the Transparency Directive necessitates the transposition of the amended provisions of the directive, which in turn creates room for national idiosyncrasies among EC Member States. If true harmonization is intended, the regulation is the correct technical measure. Moreover, as enforcement is part of the law as it works in practice, in order to create the full benefit of harmonization, enforcement measures need to be harmonized by regulation as well.

\footnotetext{
${ }^{50}$ For example, the markets may learn that a business partner hedged itself against the negative outcome of an important tender or licensing procedure by purchasing long positions in its most important competitor. As this method may be understood as anti-competitive, we may see tender or licensing conditions ban certain types of economic hedging which de facto renders hedging useless.

${ }^{51}$ See Fleischer/ Schmolke, supra n. 10, at 404 et seq.
} 


\section{The Combined Model: EOR and EOD}

If CESR intends to move forward with its proposal despite the arguments presented in this article, a combination of a reporting and a notification approach may reduce the negative impact of the CESR proposal in its current form.

It is said to be customary in the City of London to disclose one's intention to the counterparty in a derivative transaction if the overall stake exceeds $15 \%$ of the issuer's overall value. Market customs tend to reflect efficient arrangements. Building on this custom, a requirement to disclose an acquirer's overall economic position that reaches the $15 \%$ threshold reduces the likelihood that derivative positions are used for takeover purposes. Below this threshold, a requirement to report to regulators facilitates enforcement (which seems to be CESR's true motivation) while it harms market efficiency and corporate governance only to a minor extent since few traders will ever reach the 15\% threshold (and if they do, the assumption of hidden ownership is well grounded).

A combination of EOD and EOR will retain the best of CESR's initiative while refraining from imposing disadvantages on European financial markets that might be felt in the future in the form of lower valuation and higher managerial agency costs than desirable.

Finally, such a solution would avoid major differences between the future European and the future U.S. regulation and retain the chance for worldwide convergence of securities laws. Rather than CESR's EOD, the U.S. is likely to adhere to VRD (supra 3.4). 


\section{E. Conclusion}

Disclosure is not beneficial per se. Since each disclosure is costly, each disclosure requirement must, from a social perspective, serve a purpose. In fact, if disclosure rules are too strict, the marginal benefits are negative. This will exactly be the case if EOD is made mandatory in Europe, as CESR suggests, by extending Articles 10 through 13 of the Transparency Directive. Less monitoring by markets as well as a decline in takeover activity will disrupt corporate monitoring and result in higher agency costs. Implementation and execution costs reduce corporate profits and render certain issuers more prone to takeovers, as investors will respond to mandatory EOD with a discount on shares of European issuers. In particular, small jurisdictions with few issuers listed at the national stock exchanges will suffer from this discount: a prerequisite of investing in a foreign jurisdiction is knowledge regarding the legal idiosyncrasies of the target jurisdiction. Acquiring this knowledge is costly, in terms of legal fees or the gain in experience by unfortunate endeavours. If there are few issuers for which the acquired knowledge may be put to use, the costs of a signgle acquisition are higher, in relative terms, as compared to jurisdictions where many potential targets reside. At pan-European level, EOD is justifiable neither from a corporate governance nor from a market efficiency perspective. The European legislature is well advised to refrain from implementing the proposal in its current form.

A common, European policy rationale for adopting EOD does not exist. The EU jurisdictions that have implemented EOD rules so far had their own policy agenda. In the UK, the peculiarities of the stock markets rendered the adoption of EOD advisable. In France, nationalistic economic politics seek to prevent national industry from being taken over by foreign acquirers. Other jurisdictions may follow said examples, either due to the peculiarities of their stock markets, or due to maintaining a level playing field when compared to French issuers. Rather than taking an apparently easy way out of the enforcement dilemma, regulators are encouraged to think about ways of how Voting Rights Disclosure may be efficiently enforced. ${ }^{52}$

The negative impact of CESR's EOD proposal on corporate governance and market efficiency will be reduced if CESR opts for a combination of EOD and EOR: acquirers whose joint - direct and derivative-based - interest in an issuer surpasses the Transparency Directive's lower thresholds $(5 \%, 10 \%)$ should be mandated to report to regulators (EOR) rather than disclose to the public (EOD); disclosure should be limited to cases where the joint holding exceeds a threshold of an interest similar to $15 \%$ of the issuer's outstanding shares.

\footnotetext{
${ }^{52}$ For a theoretical exercise see supra n. 38.
} 